\title{
Structure of Ovaries and Oogenesis in Dermapterans. II. The Nurse Cells, Nuage Aggregates and Sponge Bodies*
}

\author{
Wacław TwORZYDŁO and Elżbieta KISIEL
}

Key words: Oogenesis, nurse cells, nuage material, sponge bodies, Dermaptera.

Wactaw TWORZYDEO, Elżbieta KISIEL, Department of Systematic Zoology, Institute of Zoology, Jagiellonian University, R. Ingardena 6, 30-060 Kraków, Poland

E-mail:w.tworzydlo@uj.edu.pl

In all studied dermapterans the ovaries are of the meroistic-polytrophic type (for a classification of ovaries and further description see BILIŃSKI 1998 \& BÜNING 1994) which means that oocytes are accompanied by highly polyploid cells of germline origin, the nurse cells or trophocytes (BÜNING 1993, 1994; MATOVA \& COOLEY 2001). The oocyte-nurse cell units arise as a result of mitotic divisions of the founder germline cell, the cystoblast (see BÜNING 1993, 1994 for a review). These units become surrounded by somatic follicular cells and constitue the ovarian follicles (=egg chambers). Our knowledge concerning the processes leading to the formation of germ cell units (germ cell cysts) relies mainly on studies of the model insect, the fruit fly, Drosophila melanogaster (KING 1970; DE CUEVAS et al. 1997; PEPLING et al. 1999). In Drosophila each cystoblast divides 4 times to generate a cyst composed of 16 sibling cells. Because all the consecutive cytokineses of the cystoblast are incomplete, the arising cells are connected by means of intercellular bridges (ring canals). Following cyst formation, one cystocyte differentiates into the oocyte, whereas the remaining 15 cells become the nurse cells (BÜNING 1994;
De CuEvas et al. 1997). In dermapterans, the oocyte-nurse cell units are composed of two cells only, the oocyte and a single nurse cell (TwORZYDŁO \& BILIŃSKI 2008; YAMAUCHI \& YOSHITAKE 1982; ZINSMEISTER \& ZINSMEISTER 1976). It should be emphasized, however, that the processes that lead to their formation may be significantly different in particular earwig subgroups. In derived families (e.g. Forficulidae) the cystoblast divides only once (BRAUNS 1912; TWORZYDŁO \& BILIŃSKI 2008), whereas in more basal taxa the cystoblast undergoes three mitoses that lead to the formation of an 8-cell complex which is secondarily split into four 2-cell clusters (YAMAUCHI \& YOSHITAKE 1982; HAAS, personal information, our unpublished data). Further development of ovarian follicles can be divided into three phases: previtellogenesis, vitellogenesis and choriogenesis (BÜNING 1993, 1994). During previtellogenesis macromolecules (e.g. rRNAs, mRNAs), proteins and organelles are gradually accumulated in the oocyte cytoplasm (ooplasm). During vitellogenesis the ooplasm becomes loaded with yolk spheres and lipid droplets. The last phase, choriogenesis, constitutes the formation of egg enve-

*Supported by funds from the grant DS/BiNoZ/IZ/780. 
lopes on the oocyte surface (BÜNING 1993, 1994; MATOVA \& COOLEY 2001).

The nutritive role of the nurse cells is facilitated by their high transcriptional activity and by the presence of intercellular bridges (ring canals) that connect nurse cells and the oocyte. Through these canals, the nurse cells supply the oocyte with various cytoplasmic constituents, e.g. mitochondria, cisternae of the ER, ribosomes and lipid droplets (BÜNING 1993, 1994; MATOVA \& COOLEY 2001; TELFER 1975). The other crucial function of the nurse cells is the synthesis of different classes of RNAs (rRNA, mRNA) that together with organelles are subsequently transferred to the ooplasm (COOLEY \& THEURKAUF 1994). We previously described the mechanisms responsible for this transport in earwig ovarian follicles (see TWORZYDŁO \& BILIŃSKI 2008 and Discussion). In this paper, we present ultrastructural analyses of the nurse cells of three forficuloid earwigs: Doru lineare, Opisthocosmia silvestris and Forficula auricularia.

\section{Material and Methods}

\section{Animals}

In this study, the following species of forficuloid earwigs were used: Forficula auricularia, Doru lineare and Opisthocosmia silvestris. Specimens of Forficula auricularia were collected in southern Poland, whereas Opisthocosmia silvestris and Doru lineare were collected in the neighborhood of Villa Tunari in Santa Cruz Province, Bolivia.

\section{Light and electron microscopy}

The ovaries were dissected from adult females and fixed in $2.5 \%$ glutaraldehyde in $0.1 \mathrm{M}$ phosphate buffer, $\mathrm{pH} 7.4$ at $18^{\circ} \mathrm{C}$, rinsed and postfixed in $1 \%$ osmium tetroxide in the same buffer. After dehydration in a series of ethanol and acetone, the material was embedded in Epon 812 (Fullam Int., Latham, NY, USA). Semithin sections $(0.7 \mu \mathrm{m}$ thick) were stained with methylene blue and examined under a Leica DMR microscope (Heidelberg, Germany). Ultrathin sections (80 nm thick) were contrasted with uranyl acetate and lead citrate according to standard protocols and analysed with a Jeol JEM 100 SX electron microscope (TEM) at $80 \mathrm{kV}$.

\section{Immunocytochemical detection of snRNAs}

For immunocytochemical studies, the ovaries were fixed in $4 \%$ formaldehyde in PBS, dehy- drated in a series of ethanol and embedded in Histocryle (Agar Scientific Ltd, Essex, UK). The ultrathin sections were collected on formvar coated nickel grids and blocked with $2 \%$ bovine serum albumin (BSA) for 20 minutes at $18^{\circ} \mathrm{C}$. Grids were incubated with the primary antibody K121 (Calbiochem, Oncogene Research Products, Cambridge, MA, USA) diluted 1:50 overnight at $4^{\circ} \mathrm{C}$. Subsequently, the grids were washed five times with PBS and incubated for 2 hours at room temperature with the secondary antibody, goat anti-mouse $\operatorname{IgG}$ conjugated to $18 \mathrm{~nm}$ gold particles (Sigma, St.Louis, MO, USA) diluted 1:100. After rinsing with PSB and bidistilled water the grids were contrasted with uranyl acetate and lead citrate and examined in a Jeol JEM 100 SX electron microscope at $80 \mathrm{kV}$. In control experiments, the grids with sections were treated exactly as described above but the incubation with the primary antibody (K121) was omitted.

\section{Results}

\section{Gross morphology of the ovaries}

The ovaries of the studied forficuloids are paired and composed of about 40 short ovarioles of the meroistic-polytrophic type. The ovarioles are attached to elongated lateral oviducts by the ovariole stalks (pedicels) and surrounded by a thick ovariole sheath. In each ovariole, three easily recognizable elements can be distinguished: the terminal filament, the germarium and the vitellarium. The anteriorly located terminal filament is a stalk of 4-6 somatic disc-shaped cells, oriented perpendicularly to the long axis of the ovariole. The germarium comprises germline stem cells, differentiating germ cells and germ cell cysts, as well as somatic cells (for details see TWORZYDŁO \& BILIŃSKI 2008). The vitellarium consists of two ovarian follicles only. The ovarian follicles are composed of two cells: an oocyte and a single nurse cell which are connected by an intercellular bridge and covered with follicular epithelium. The process of oogenesis in earwigs can be divided into 4 developmental stages: early previtellogenesis (1), late previtellogenesis (2), vitellogenesis (3) and choriogenesis (4). In this study, we present analyses of previtellogenic and vitellogenic ovarian follicles, with special reference to the morphology and ultrastructure of the nurse cells.

Because the organization of the follicles and the ultrastructure of the nurse cells in all three studied species (Doru lineare, Opisthocosmia silvestris and Forficula auricularia) are quite similar, the following description applies to all of the examined species. The characteristic (unique) features 
and differences between species are described in a separate paragraph at the end of the Results section (see below).

\section{Early previtellogenesis}

The early previtellogenic ovarian follicles are in direct contact with the germarium and are composed of relatively small, lens-shaped oocytes and slightly larger nurse cells. The nurse cell nuclei are approximately spherical and contain heterochromatin aggregations and dense nucleoli located in their karyoplasm. They are surrounded by a slightly folded nuclear envelope. The trophocyte cytoplasm contains numerous mitochondria, ribosomes, elements of rough endoplasmic reticulum (RER) and multivesicular bodies (not shown).

\section{Late previtellogenesis and vitellogenesis}

A late previtellogenic nurse cell occupies about $70 \%$ of the ovarian follicle volume. Its cytoplasm is comprised of free ribosomes, mitochondria, multivesicular bodies and variously shaped elements of RER (Figs 2-6). Frequently the RER cisternae are arranged concentrically (Fig. 2). Aggregations of electron-dense nuage material are located in the close vicinity of the nuclear envelope. The nuage material is usually surrounded by more "transparent", ribosome-free cytoplasm (Fig. 7).

Immunostaining with the K121 antibody against the TMG cap present in snRNAs showed that the nuage aggregations are almost negative (do not contain snRNAs), while the cytoplasm of the nurse cell is strongly immunoreactive (Figs 8,9). The nurse cell nucleus is large and attains a characteristic "ameboid" shape. Its highly folded envelope is pierced with numerous, densely packed pore complexes (Fig. 3, encircled). The karyoplasm contains heterochromatin aggregations and nucleoli.

During vitellogenesis, yolk spheres and lipid droplets are gradually accumulated in the ooplasm reserve materials. This is followed by significant growth of the oocyte volume. Simultaneously (as vitellogenesis progresses) the nurse cell occupies a smaller and smaller compartment of the ovarian follicle. At the end of vitellogenesis the nurse cell cytoplasm is transferred into the oocyte, leading to the degeneration of the nurse cell (see TWORZYDEO \& BILIŃSKI 2008 for further details).

\section{Unique features of the nurse cells}

\section{a) Opisthocosmia silvestris}

Characteristic vesicles are present (Fig. 6) in early and late previtellogenic nurse cells of this species, in addition to ribosomes, mitochondria, ER elements and nuage aggregations. TEM analysis revealed that these structures are surrounded by a limiting membrane incrustated with ribosomes and are filled with amorphous material of medium electron density (Fig. 6). Vitellogenic nurse cells of $O$. silvestris contain large lipid droplets (Fig. 1).

\section{b) Doru lineare}

In this species, apart from the "canonical" nuage aggregations, the nurse cell cytoplasm contains characteristic complexes of nuage and RER (Figs 2,4). These complexes are composed of twisted RER cisternae and branched accumulations of nuage material (Figs 2, 4).

\section{Discussion}

The ultrastructure of the nurse cells in all insect species is rather similar and reflecs their function (TELFER 1975; BÜNING 1994). As a rule, these cells become polyploid and therefore their nuclei are relatively large, and comprise prominent, highly active nucleoli. During the subsequent stages of oogenesis, the nuclear envelope of the nurse cells becomes highly folded, leading to an increase of the nuclear surface and more efficient nucleo-cytoplasmic transport. The envelope is pierced with numerous pore complexes responsible for the transport of ribonucleoproteins (RNPs) from the nucleus to the surrounding cytoplasm. In many species, aggregations of electron-dense granular material, called nuage, occur in the close vicinity of the nuclear envelope (reviewed in RAZ 2000). It is believed that nuage represents precursors of the determinants of the germ cell fate, the germinal granules (KLAG 1977, 1982; SAFFMAN \& LASKO 1999; KLOC et al. 2004; BILIŃSKI et al. 2004). Although the list of molecular components of nuage material is still incomplete, it has been shown that accumulations of nuage contain both proteins and mRNAs (KLAG 1982, 1984; KLOC et al. 2002; BILIŃSKI et al. 2004; LINDER \& LASKO 2006; EULALIO et al. 2007). Immunocytochemical studies have shown that in Xenopus laevis the nuage aggregates contain Xcat 2 mRNA, Dead box helicase XVLG1 and constituents of the spliceosomes, the Sm proteins (BILIŃSKI et al. 2004). Quite suprisingly, other components of the splicing machinery, such as coilin, SMN proteins and most remarkably snRNAs, are absent from the nuage (BILIŃSKI et al. 2004). Our immunolocalization analysis showing the absence of snRNAs in earwig nuage aggregations is in line with these findings. It has also been revealed that nuage contains several components characteristic for the processing bodies (P bodies) - tiny cytoplasmic structures involved in mRNA metabolism (SEY- 

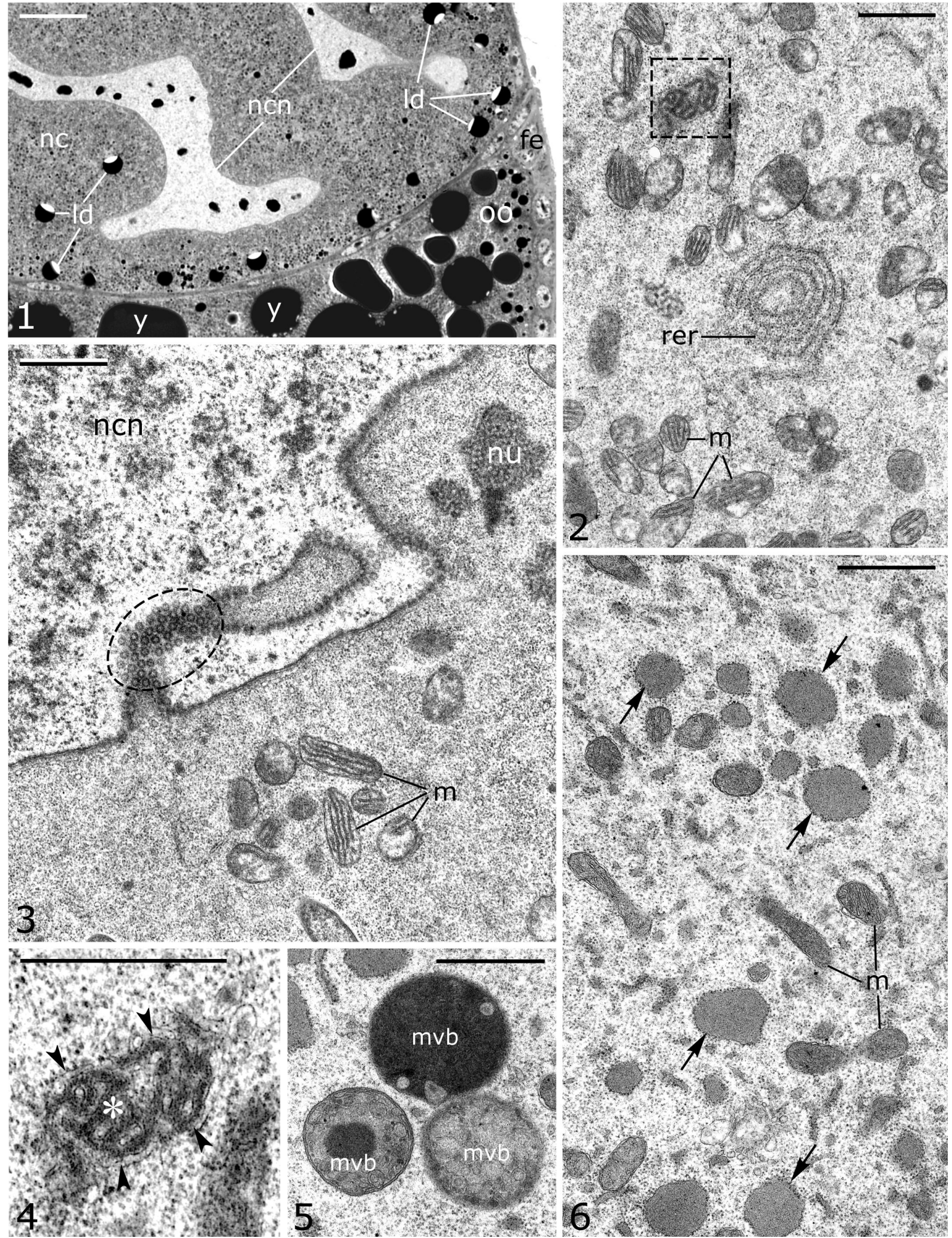

Figs 1-6. Morphology of the nurse cells. Fig. 1. Opisthocosmia silvestris. Fragment of the vitellogenic ovarian follicle. Follicular epithelium (fe), nurse cell (nc), nurse cell nucleus (ncn), oocyte (oo), lipid droplets within nurse cell cytoplasm (ld), yolk spheres (y). Semithin Epon section, methylene blue. Figs 2-4. Doru lineare. Fragment of the late previtellogenic nurse cell. Complex of RER (arrowheads in Fig. 4) and nuage material (asterisk in Fig. 4) is boxed in Fig. 2 and magnified in Fig. 4; elements of RER (rer), nurse cell nucleus (ncn), mitochondria (m), aggregations of nuage material (nu), nuclear pore complexes are encircled. Ultrathin Epon section, TEM. Figs 5-6. Opisthocosmia silvestris. Fig. 5. Multivesicular bodies (mvb) in the nurse cell cytoplasm. Fig. 6. Fragment of the late previtellogenic nurse cell. Note numerous polymorphic electron-dense vesicles filled with granular electron dense material and surrounded by a limiting membrane covered with ribosomes (arrows), mitochondria (m). Ultrathin Epon section, TEM. Bars $=25 \mu \mathrm{m}$ in Fig. 1; $1 \mu \mathrm{m}$ in Figs 2-6. 


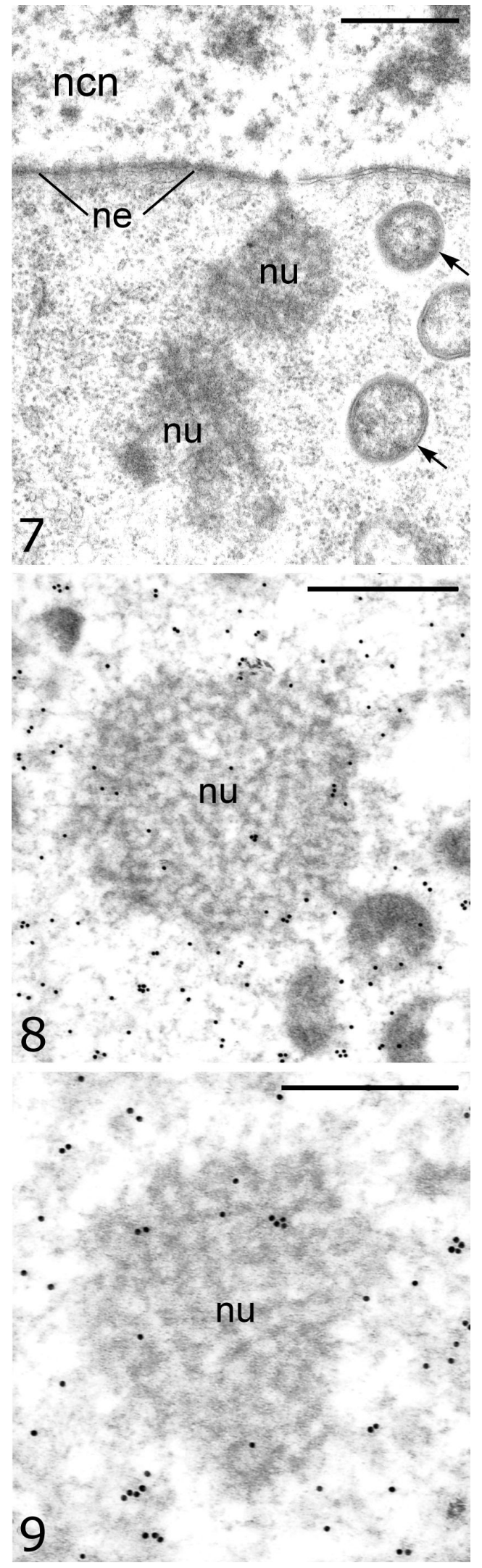

Figs 7-9. Nuage aggregations. Fig. 7. Doru lineare. Fragment of the nurse cell nucleus (ncn) and perinuclear cytoplasm. Nuclear envelope (ne), nuage aggregations (nu) endosymbiotic microorganisms (arrows). Ultrathin Epon section, TEM. Figs 8-9. Forficula auricularia. Fragment of the perinuclear cytoplasm with nuage aggregations (nu). Ultrathin Histocryle section labelled with K121 antibody. Scale bars $=1 \mu \mathrm{m}$
DOUX \& BROWN 2006; EULALIO et al. 2007; LIN et al. 2008; GALLO et al. 2008). In the light of this finding it was suggested that nuage is a germline equivalent of somatic $\mathrm{P}$ bodies (SEYDOUX \& BROWN 2006; EULALIO et al. 2007; JAGLARZ et al. 2009).

Although the mechanism of mRNA transport and localization has been extensively studied (see below), the structrural aspects of this process remain practically unknown. Morphological studies (KLAG \& BILIŃSKI 1993; WILSCH-BRÄUNINGER et al. 1997; THEURKAUF \& HAZELRIGG 1998; SNEE $\&$ MACDONALD 2003) showed that mRNA molecules are transported within relatively large, electron-dense aggregates that have been variously termed, e.g. sponge bodies (WILSCH-BRÄUNINGER et al. 1997), vesicular tubular-shaped particles (VTS, KIM 2003), aggregations of nuage (BILIŃSKI \& JAGLARZ 1999) or nuage-mitochondria complexes (KLAG \& BILIŃSKI 1993). Microtubules were observed in the close vicinty of these aggregates, suggesting a role of these cytoskeletal elements in mRNA localization (KLAG \& BILIŃSKI 1993; WILSCH-BRÄUNINGER et al. 1997; THEURKAUF \& HAZELRIGG 1998; BILIŃSKI \& JAGLARZ 1999). Because the molecular composition of the transported aggregates was not analysed, it is unclear whether all mRNA species are transported in the same way or whether the individual aggregate contains only one or more mRNA species. We showed that in the nurse cell cytoplasm of Doru lineare, besides the "canonical" nuage aggregations, characteristic complexes of nuage and RER are present. These RER/nuage complexes are remarkably similar morphologically to the sponge bodies found in the cytoplasm of the germ cells of the fruit fly, Drosophila melanogaster (WILSCH-BRÄUNINGER et al. 1997). In this context we suggest that RER/nuage complexes in Doru are implicated in mRNA translocation, as are sponge bodies in Drosophila.

We have shown that the nurse cell cytoplasm of the studied earwig species contains numerous organelles, e.g. ribosomes, RER cisternae and multivesicular bodies, revealing the high synthetical activity of these cells. In one species, Opisthocosmia silvestris, in addition to these structures, characteristic vesicles filled with granular material surrounded by a membrane covered with ribosomes are present. The function of these structures remains unknown.

During the final stages of oogenesis, the nurse cell cytoplasm with various molecules and organelles is transported to the oocyte through intercellular bridges (COOLEY \& THEURKAUF 1994; MAHAJAN-MIKLOS \& COOLEY 1994; MATOVA \& COOLEY 2001). During this transfer the nurse cell nucleus does not enter the oocyte and is retained in the cell center. In holometabolous insects this position of the nurse cell nucleus during the transfer 
of cytoplasm is maintained by cytoskeletal elements, i.e. actin cables in higher dipterans, including Drosophila melanogaster (MATOVA et al. 1999; COOLEY et al. 1992; CANT et al. 1994; HUDSON \& COOLEY 2002) or microtubular cages in hymenopterans (BILIŃSKI \& JAGLARZ, 1999). In the previous study we showed that in earwigs, as in phthirapterans, the central position of the nurse cell nucleus is maintained not by cytoskeletal elements, but solely by elongated extensions of the nuleus (ŻELAZOWSKA \& BILIŃSKI 2001; TWORZYDLO \& BILIŃSKI 2008).

\section{Acknowledgements}

We are grateful to Professor Szczepan M. BILIŃSKI for reading the manuscript, his critical comments and suggestions, and for providing the specimens of Bolivian earwigs. Skillful technical assistance from Ms.Władysława JANKOWSKA is acknowledged.

\section{References}

BILIŃSKI S. M. 1998. Introductory remarks. Folia Histochem. Cytobiol. 36: 143-145.

BILIŃSKI S. M., JAGLARZ M. K. 1999. Organization and possible functions of microtubule cytoskeleton in hymenopteran nurse cells. Cell Mot. Cytoskeleton 43: 213-220.

BILIŃSKi S. M., JAGLARZ M. K., SZYMAŃSKA B., ETKIN L. D., KLOC M. 2004. Sm proteins, the constituents of the spliceosomes, are components of nuage and mitochondrial cement in Xenopus oocytes. Exp. Cell Res. 299: 171-178.

BRAUNS F. 1912. Die Entstehung der Nährzelle und die Bedeutung derselben für das wachsende Ei bei Forficula auricularia L. Sitzungsber. Abhandl. Ges. Rostock (NF4): 99-141.

BÜNING J. 1993. Germ cell cluster formation in insect ovaries. Int. J. Insect Morphol. Embryol. 22: 237-253.

BÜNING J. 1994. The Insect Ovary. Ultrastructure, Previtellogenic Growth and Evolution. Chapman \& Hall, London.

Cant K., Knowles B. A., Mooseker M. S., Cooley L. 1994. Drosophila singed, a fascin homolog, is required for actin bundle formation during oogenesis and bristle extension. J. Cell Biol. 125: 369-380.

COOley L., TheurKauf W. E. 1994. Cytoskeletal functions during Drosophila oogenesis. Science 266: 590-596.

COOlEY L., VERHEYEN E., AYERS K. 1992. chickadee encodes a profilin required for intercellular cytoplasm transport during Drosophila oogenesis. Cell 69: 173-184.

DE Cuevas M., Lilly M. A., SpRadling A. C. 1997. Germline cyst formation in Drosophila. Ann. Rev. Genet. 31: 405-428.

Eulalio A., Behm-Ansmant I., IZAurRalde E. 2007. P bodies: at the crossroads of post-transcriptional pathways. Nat. Rev. Mol. Cell Biol. 8: 9-22.

Gallo C. M., Munro E., Rasoloson D., Merritt C., SeyDOUX G. 2008. Processing bodies and germ granules are distinct RNA granules that interact in C. elegans embryos. Dev. Biol. 323: 76-87.

HUDSON A. M., COOLEY L. 2002. Understanding the function of actin-binding proteins through genetic analysis of Drosophila oogenesis. Ann. Rev. Gen. 36: 455-488.

JAGLARZ M. K., JABŁońsKa A., Kisiel E., BILIŃSKi S. M. 2009. Diversification of follicular cells in the ovaries of the horse fly, Haematopota italica (Diptera: Tabanidae). Similarities and differences with the Drosophila model system. Folia biol. (Kraków) 57: 57-63.
KIM C. 2003. Vesicular tubular-shaped particles transported from nurse cells to oocytes in Drosophila egg chambers. Mol. Cell 17: 140-143.

KING R. C. 1970. Ovarian Development in Drosophila melanogaster. Academic Press, New York.

KLAG J. 1977. Differentiation of primordial germ cells in embryonic development of Thermobia domestica, Pack. (Thysanura): an ultrastructural study. J. Embryol. Exp. Morph. 38: 93-114.

KLAG J. 1982. Germ line of Tetrodontophora bielanensis (Insecta, Collembola). Ultrastructural study on the origin of primordial germ cells. J. Embryol. Exp. Morph. 72: 183-195.

KLAG J. 1984. Germ line of Tetrodontophora bielanensis (Insecta, Collembola). 4. Nucleolus-like bodies extruded in toto from the nuclei of primordial germ cell become part of the "nuage". Cytobios 40: 7-20.

KLAG J., BILIŃSKI S. 1993. Oosome formation in two ichneumonid wasps. Tissue Cell 25: 121-128.

KlOC M., BilińSKI S. M., ETKIN L. D. 2004. The Balbiani body and germ cell determinants: 150 years later. Curr. Top. Dev. Biol. 59: 1-36.

KLOC M., ZEARFOSS R. N., ETKIN L. D. 2002. Mechanisms of subcellular mRNA localization. Cell 108: 533-544.

Lin M., Jiao X., GRIMA D., NewbuRy S. F., KiledJIAN M., CHOU T. 2008. Drosophila processing bodies in oogenesis. Dev. Biol. 322: 276-288.

LINDER P., LASKO P. 2006. Bent out of shape: RNA unwinding by the DEAD-box helicase Vasa. Cell 125: 219-221.

MAHAJAN-MiKLOS S., COOLEY L. 1994. Intercellular cytoplasm transport during Drosophila oogenesis. Dev. Biol. 165: 336-351.

Matova N., CoOley L. 2001. Comparative aspects of animal oogenesis. Dev. Biol. 231: 291-320.

Matova N., Mahajan-Miklos S., Mooseker M. S., COOLEY L. 1999. Drosophila Quail, a villin-related protein, bundles actin filaments in apoptotic nurse cells. Development 126: 5645-5657.

Pepling M. E., De Cuevas M., Spradling A. C. 1999. Germline cysts: a conserved phase of germ cell development? Trends Cell Biol. 9: 257-262.

RAZ E. 2000. The function and regulation of vasa-like genes in germ cells development. Genome Biol. 1: 10171-10177.

SAFFMAN E. E., LASKO P. 1999. Germline development in vertebrates and invertebrates. Cell Mol. Life Sci. 55: 1141-1163.

SEYdouX G., BRown R. E. 2006. Pathway to totipotency: lessons from germ cells. Cell 127: 891-904.

SNEE M. J., MACDONALD P. M. 2003. Live imaging of nuage and polar granules: evidence against a precursor-product relationship and a novel role for Oskar in stabilization of polar granule components. J. Cell Sci. 117: 2109-2120.

TELFER W. H. 1975. Development and physiology of the oocyte - nurse cell syncytium. Adv. Insect Physiol. 11: 223-319.

THEURKAUF W. E., HAZELRIGG T. I. 1998. In vivo analyses of cytoplasmic transport and cytoskeletal organization during Drosophila oogenesis: characterization of multi-step anterior localization pathway. Development 125: 3655-3666.

TwORZYDŁO W., BILIŃSKI S. M. 2008. Structure of ovaries and oogenesis in dermapterans. I. Origin and functioning of the ovarian follicles. Arthropod Struct. Dev. 37: 310-320.

Wilsch-BRÄUNINGER M., SChWARZ H., NÜSSlEIN-VOLHARD C. 1997. A sponge-like structure involved in the association and transport of maternal products during Drosophila oogenesis. J. Cell Biol. 139: 817-829.

YAMAUCHI H., YoshiTAKE N. 1982. Origin and differentiation of the oocyte - nurse cell complex in the germarium of the earwig, Anisolabis maritima Borelli (Dermaptera: Labiduridae). Int. J. Insect Morphol.Embryool. 12: 293-305. ZINSMEISTER P. P., ZINSMEISTER D. D. 1976. Ultrastructural aspects of the earwig ovary. J. Insect Physiol. 22: 1057-1060.

ŻELAZOWSKA M., BILIŃSKI S. M. 2001. Ultrastructure and function of nurse cells in phthirapterans. Possible function of ramified nurse cell nuclei in the cytoplasm transport. Arthropod Struct. Dev. 30: 135-143. 